\title{
ECT DAMAGE INDICATES STM DIVIDED INTO STM CONTROL \& LTM TRACES: NEUROLOGICAL DEFINITION OF "CONFUSION"
}

\author{
Eugen Tarnow \\ Avalon Business Systems, Inc. \\ 18-11 Radburn Road, Fair Lawn, NJ 07410, USA
}

\begin{abstract}
Recently it was shown that short term memory (STM) free recall consists of two stages: the first few recalls empty working memory and a second stage, a reactivation stage, concludes the recall (Tarnow, 2015; for a review of the theoretical predictions see Murdock, 1974). Bayley et al (2000) investigated free recall in people who had undergone Electroconvulsive therapy (ECT) and found that both recency and primacy effects were normal. Here I investigate this further, and argue that this finding suggests a division of STM between STM Control and long term memory (LTM) traces and that STM Control is not effected by ECT.

Serial position probabilities from an investigation of Bayley et al (2000) were used to compare 11 subjects with ECT treatments to a control group and to a group of Alzheimer's subjects.

The free recall probabilities are found to be separable into the serial position curves and the overall probability of recall. This suggests that STM is separable into an STM Control structure (the serial position curve responsible for working memory and reactivation functions) and LTM traces (the overall probability of recall).

Using the ECT review of Abbott et al (2014a) showing excess activity in MTL and lacking activity in the frontal lobes I suggest that STM Control is overworked trying to establish stable patterns in LTM. It could be that the confusion resulting from ECT is due to the failure of this process, suggesting a neurological definition of confusion.
\end{abstract}

Key words: electroconvulsive therapy (ECT), free recall, working memory, short term memory (STM), long term memory (LTM), serial position curve, neuroplasticity

\section{Introduction}

Progress in brain science has often occurred by studying different types of brain damage that leave particular signatures on cognition (Rosenbaum et al, 2014). In this article I focus on the temporary damage of Electroconvulsive Therapy (ECT) on short term memory (STM), in particular to free recall in which subjects attempt to recall as many items as possible from a presented list.

It was recently shown explicitly that free recall is a well-defined two stage process (Tarnow, 2015; this had been suggested before, for a review see Murdock, 1974; see also Talmi et al (2005)). In the first stage working memory is emptied and in the second stage items are reactivated.

The serial position curve displays the probability of recall as a function of the item presentation order. Working memory is typically responsible for recency (the increase in 
probability of recall of recent items); the second stage recall shows some primacy (increase in probability of recall of early items) but no recency (Tarnow, 2015).

Among the side effects of ECT is a decrease in STM (Ingram et al, 2008). Bayley et al (2000) compared the effect on free recall from Alzheimer's disease (AD) with mild cognitive impairment or mild dementia and ECT and found that there was a $46 \%$ decrease in the number of items recalled in both conditions.

For Alzheimer's disease the free recall serial position curve changed and the authors concluded that a reduction in the primacy effect was an "early and ubiquitous feature" of the memory impairment of AD. Using a subset of the same data, Tarnow (2016a) showed that early Alzheimer's disease is associated with a loss of items from the second stage. Because this loss is very similar to the loss during acute cannabis usage, the intersection of the two localizes the second stage of free recall to the CA1 area of the hippocampus (Tarnow, 2016a; for a review of the importance of the CA1 area in memory see, for example, Kandel et al, 2014;). In mouse models of early Alzheimer's disease, Roy et al (2016) could activate memories (that were otherwise inaccessible) using external electrodes in the hippocampal region, also suggesting AD effects the hippocampal region and, more importantly, that the hippocampal region can play a role in activating memories. As Alzheimer's disease progresses to the clinically diagnostic stage, working memory is impaired (Tarnow, 2016b), though where the dysfunction is located seems to be a complex issue (Goldman-Rakic, 1994) and there are also indications that in addition to a geographic progression there might be an overall decline in neuroplasticity (Teter \& Ashford, 2002).

The ECT effect on free recall appears different. While there was a significant loss of memory using free recall, there was no change in the corresponding serial position curve in the sense that it still had both a recency and a primacy component (Bayley et al, 2000).

In this paper I will explore the meaning of decreased free recall with no structural changes to the serial position curve occurring in ECT.

\section{Method}

Subjects. The subjects were described in Bayley et al (2000) in some detail and are summarized here. The 11 ECT subjects were on average 53 years old and had 15 years of education. 8 of the subjects received bilateral ECT, two subjects unilateral ECT and one subject a combination of unilateral and bilateral treatments. No scopolamine was administered (John Olichney, private communication). The 50 AD subjects were diagnosed with probable or possible AD, the mean age of the AD subjects was 74 years old and they had an average of 14 years of education. A control group of 50 subjects had an average age of 74 and 14 years of education.

Study procedure. The California Verbal Learning Test (CVLT) was administered to the subjects as part of a large battery of neuropsychological tests (see Bayley et al, 2000):

"Neuropsychological tests were administered to the patients both prior to ECT treatment and approximately 3 to 7 hours following the last of a series of treatments (range of treatments 5 5-11, M 5 7.4). The pre-ECT and ECT tests were separated by an average of 20.8 days (range 13-35). In order to reduce interference between test sessions, alternate forms of the CVLT (Form I: Delis et al., 1987a; and Form II: Delis et al., 1987b) were used on the 2 test days. The order of administration of alternate forms was counterbalanced 
across participants. Only data obtained on the day of ECT are reported here, and are derived from Form I for 5 participants and from Form II for 6 participants”.

\section{Results}

The results of Bayley et al (2000) are summarized in Table 1. The largest to smallest ECT effect appears to be free recall after interference (whether delayed or not), then free recall without interference (any trial) and then recognition. That the effect varies widely might suggest indiscriminate failures. But Bayley et al (2000) found that the serial position curve of the ECT group was similar in form to that of the NC group as middle item recall was significantly reduced compared to primacy $(p=.02)$ and recency $(p=.03)$ recall while primacy and recency recall did not differ significantly $(p=.29)$ from each other.

Table 1

Result summary of Bayley et al (2000)

\begin{tabular}{|l|c|c|c|c|}
\hline \multicolumn{1}{|c|}{ Variables } & Normal & ECT & Ratio ECT to NC results & Effect \\
\hline Recognition Discriminability & .923 & .8 & $87 \%$ & $13 \%$ \\
\hline Free recall trial 1 & 6.4 & 3.5 & $55 \%$ & $45 \%$ \\
\hline Free recall trial 5 & 11.7 & 6.3 & $54 \%$ & $46 \%$ \\
\hline Free recall trials 1-5 & 48.3 & 27.4 & $57 \%$ & $43 \%$ \\
\hline Short-delay free recall after interference & 9.2 & 1.5 & $16 \%$ & $84 \%$ \\
\hline Long-delay free recall after interference & 9.8 & 1.6 & $16 \%$ & $84 \%$ \\
\hline
\end{tabular}

I went one step further and performed ANOVAs on each of the positions of the serial position curve in the free-recall-without-interference trials. The results are shown in Fig. 1 which displays the $p<.05 \mathrm{z}$-scores in ECT and AD subjects (uncorrected for multiple comparisons; z-scores based on the standard deviations of the Normal subjects). The serial position curve is very different for AD subjects, showing a definite trend, but seemingly only with random changes for the ECT subjects. However, the total recall differs from normal for both the fifty AD subjects $\left(p=2 \cdot 10^{-13}, F=72\right)$ and the eleven ECT subjects $\left(p=8.4 \cdot 10^{-5}, F=17.9\right)$.

So far the ECT subjects have the same serial position curve as normal subjects but differ by the overall recall. Is it possible to model the ECT subjects as normal subjects at a multiplicatively reduced recall? Fig. 2 displays the serial position curve for a simulation in which the normal group's average recall was reduced to $56 \%$ for each serial position, the reduction of the total recall in both ECT and AD subjects. Again, the serial position curve is very different for AD subjects but seemingly only with random changes for ECT subjects. In this comparison there is by design no difference in total recall for the AD subjects $(p=.91)$, nor for the ECT subjects $(p=.77)$. Thus the ECT subjects cannot be distinguished from normal subjects with a $56 \%$ recall.

\section{Discussion}

Thus the ECT effect on free recall appears to be separable into two functions: the serial position curve and the overall probability of recall. The serial position curve (working memory and reactivation as in Tarnow, 2015) may represent an STM control structure (STM Control). Since short term memory appears to be activated long term memory (see, for example, Tarnow, 2009; Talmi et al, 2005 who show that the beginning of the 

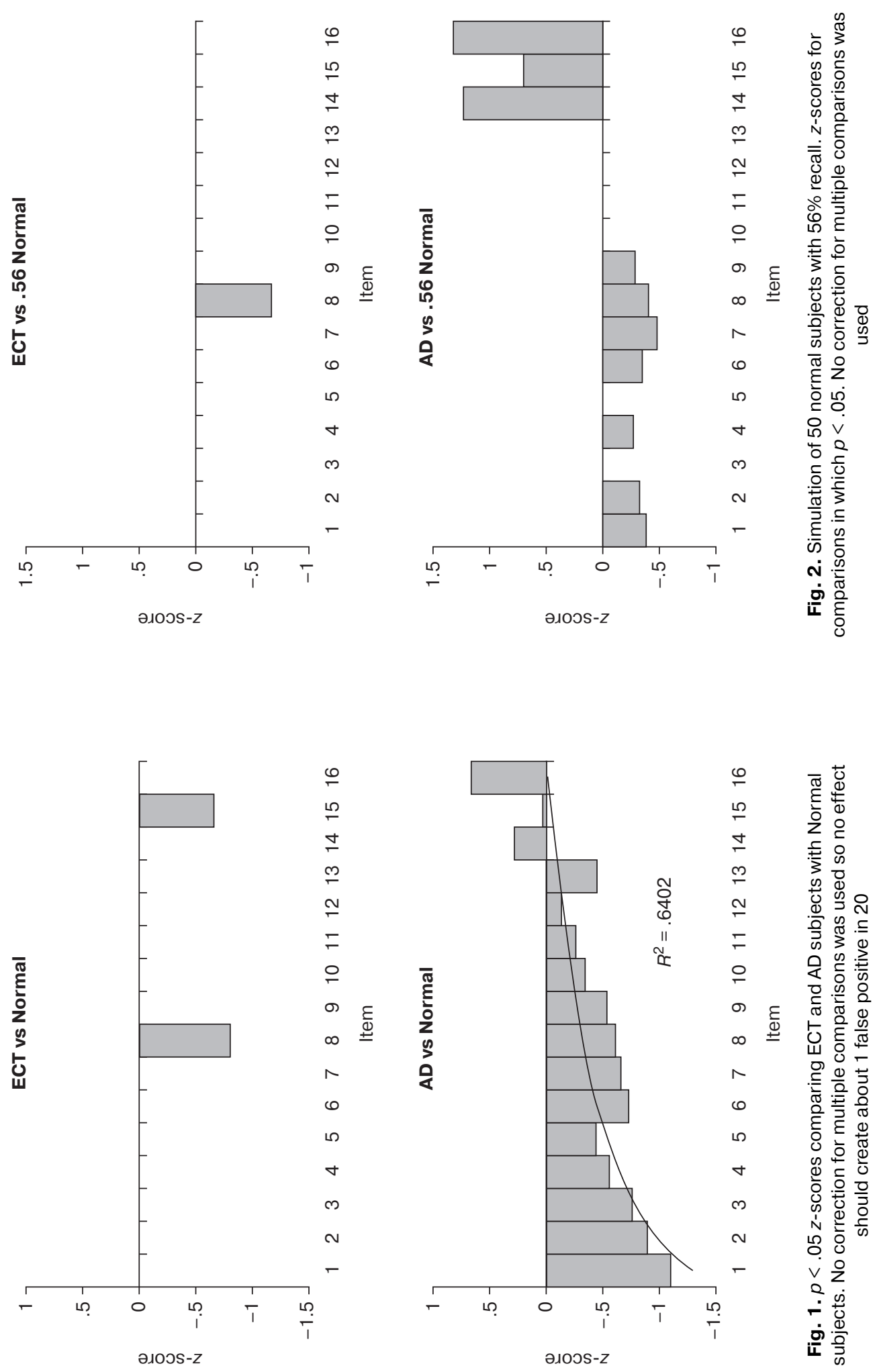
serial position curve activates LTM but the end does not), the overall probability of recall may be related to difficulties in activating the long term memory item traces (also indicated by the lowered chance of recognition discriminability (Table 1).

In other words, it seems that the results suggest a division of STM into a STM control structure (STM Control) and long term memory item traces kept active or reactivated by STM control. Both parts of STM Control, the first and second stages of free recall, appear intact relative to each other. It appears that ECT differentially affects the second function, the long term memory traces, or the connections between STM Control and the long term memory traces.

The Bayley et al (2000) data also show other losses consistent with item rather than functional effect (Table 2). Test practice, presumably a property of STM Control, shows no change but interference, presumably a property of the number of item features remaining intact, shows a very large decrease in ECT compared to Normal.

Table 2

Various properties of results in Bayley et al (2000)

\begin{tabular}{|l|l|l|l|l|}
\hline \multicolumn{1}{|c|}{ Property } & \multicolumn{1}{|c|}{ Definition } & \multicolumn{1}{c|}{ Normal } & \multicolumn{1}{c|}{ ECT } & Ratio ECT to Normal \\
\hline Test practice & Trial 5/Trial 1 & 1.828125 & 1.8 & $98 \%$ \\
\hline Interference & Short-delay after interference / Trial 5 & .786325 & .238095 & $30 \%$ \\
\hline Decay rate & Long delay after interference/Short delay & 1.065217 & 1.066667 & $100 \%$ \\
\hline
\end{tabular}

The memory decay rate is not affected (see Table 2), suggesting that the ECT effect does not interfere with the biochemistry. The decay rate is negative which is to be expected if the decay function is convex (as in Tarnow, 2008) with the interfering items disappearing more quickly than the original items.

A spatial division of memory centers within the brain has been discussed before (see, for example, Alvarez \& Squire, 1994; McClelland et al, 1994) consisting of the Medial Temporal Lobe (MTL) and the Frontal Lobes (FL) and, as mentioned above, the STM reactivation stage is in the hippocampal area, part of MTL. While it is not known where working memory resides, it would seem to be in an area relatively unaffected by ECT, perhaps also in MTL. The LTM would then be located in FL.

Two recent investigations support this conclusion in rats, I mentioned Roy et al (2016) before. Kitamura et al. (2017) found activated nerve cells both in the hippocampal region (part of MTL) and the cortex during recall. While they assumed the activated nerve cells in the hippocampal region stored the memory, it could be that they simply were activating the cortical cells that represented the actually event. If they blocked the communication between the hippocampal region and the cortex during the conditioning, no long term memory formed of the conditioned episode. They were able to reactivate the memory in the cortex externally as long as a few days had passed since the conditioning episode.

Why would STM Control not be effected by ECT? The electric field of the ETL electrodes decreases as one moves back from the bilateral electrodes (Lee et al, 2014), perhaps it also decreases towards the center of the brain; in either case a somewhat smaller sized field might cause less of an effect. It could also be that STM Control is more robust towards destruction by electric fields. It could also be that ECT may separately disrupt particular brain system such as the RAS, NE, 5HT, or ACh systems or interact with neuroplasticity. 
A symptom of ECT is confusion and it has been thought that "post-ECT confusion might represents an extension of the process causing minimal memory deficits" (Summers et al, 1979). An STM Control that fails to properly activate a long term memory trace might be a closer description of this confusion.

In a review article, Abbott et al (2014a) showed that ECT "anticonvulsant effects appear to be predominately frontally mediated and neurotrophic effects appear to be focused on the medial temporal lobes". The same group also detected a connectivity and volume increase in the hippocampal area (Abbott et al, 2014b). It is plausible that decreased FL activity occurs because of the ECT effect and that failed FL reactivations from MTL causes MTL to become overactive.

Using the proportional relationship between activation level and probability of recognition (Tarnow, 2008), I estimate the effect from ECT to be the lower recognition $12 \%$ from Table 1 . This effect leads to a $43 \%$ decline in the ability for MTL to internally reactivate the damaged memories and a $81 \%$ decline under conditions of interference. This presumably reflects the increasing difficulty of internal reactivation of effected items/ item connections and increasing difficulty of distinguishing between two sets of effected items.

The memory decay rate is not affected (see Table 2), suggesting that the ECT damage does not interfere with the biochemistry (which might be the replenishment of vesicles in the readily releasable pool, see Tarnow, 2009). The decay rate is negative which is to be expected if the decay function is convex (as in Tarnow, 2008) with the interfering items disappearing more quickly than the original items.

\section{Acknowledgement}

Data from Bayley et al. was provided by Peter Bayley.

\section{REFERENCES}

Abbott, C.C., Gallegos, P., Rediske, N., Lemke, N.T., \& Quinn, D.K. (2014a). A review of longitudinal electroconvulsive therapy: neuroimaging investigations. Journal of geriatric psychiatry and neurology, 27(1), 33-46. doi: 10.1177/0891988713516542.

Abbott, C.C., Jones, T., Lemke, N.T., Gallegos, P., McClintock, S.M., Mayer, A.R., ,.. \& Calhoun, V.D. (2014b). Hippocampal structural and functional changes associated with electroconvulsive therapy response. Translational psychiatry, 4(11), e483. doi: 10.1038/tp.2014.124.

Alvarez, P., \& Squire, L.R. (1994). Memory consolidation and the medial temporal lobe: a simple network model. Proceedings of the National Academy of Sciences, 91(15), 7041-7045. doi: 10.1073/ pnas.91.15.7041.

Bayley, P.J., Salmon, D.P., Bondi, M.W., Bui, B.K., Olichney, J., Delis, D.C., ... \& Thal, L.J. (2000). Comparison of the serial position effect in very mild Alzheimer's disease, mild Alzheimer's disease, and amnesia associated with electroconvulsive therapy. Journal of the International Neuropsychological Society, 6(03), 290-298. doi: 10.1017/S1355617700633040.

Crow, T.J. \& Grove-White, I.G. (1973). An analysis of the learning deficit following hyoscine administration to man. British Journal of Pharmacology, 49 (2), 322-327. doi: 10.1111/j.1476-5381.1973.tb08379.x.

Dominique, J.F., Roozendaal, B., Nitsch, R.M., McGaugh, J.L., \& Hock, C. (2000). Acute cortisone administration impairs retrieval of long-term declarative memory in humans. Nature neuroscience, 3(4), 313-314. 
Frith, C.D., Richardson, J.T.E., Samuel, M., Crow, T.J., \& McKenna, P.J. (1984). The effects of intravenous diazepam and hyoscine upon human memory. The Quarterly Journal of Experimental Psychology, 36(1), 133-144. doi: 10.1080/14640748408401507.

Goldman-Rakic, P.S. (1995). Cellular basis of working memory. Neuron, 14(3), 477-485. doi: 10.1016/0896-6273(95)90304-6

Kandel, E.R., Dudai, Y., \& Mayford, M.R. (2014). The Molecular and Systems Biology of Memory. Cell, 157(1), 163-186.

Kitamura, T., Ogawa, S.K., Roy, D.S., Okuyama, T., Morrissey, M.D., Smith, L.M., ... \& Tonegawa, S. (2017). Engrams and circuits crucial for systems consolidation of a memory. Science, 356(6333), 73-78. doi: 10.1126/science.aam6808

Lee, W.H., Lisanby, S.H., Laine, A.F., \& Peterchev, A.V. (2014, August). Stimulation strength and focality of electroconvulsive therapy and magnetic seizure therapy in a realistic head model. Engineering in Medicine and Biology Society: Proceeding of 36th Annual International Conference of the IEEE (pp. 410-413). Chicago: IEEE. doi: 10.1109/EMBC.2014.6943615.

McClelland, J.L., McNaughton, B.L., \& O'reilly, R.C. (1995). Why there are complementary learning systems in the hippocampus and neocortex: insights from the successes and failures of connectionist models of learning and memory. Psychological review, 102(3), 419. doi: 10.1037/0033-295X.102.3.419.

Murdock, B.B. (1974). Human memory: Theory and data. Lawrence Erlbaum.

Rosenbaum, R.S., Gilboa, A., \& Moscovitch, M. (2014). Case studies continue to illuminate the cognitive neuroscience of memory. Annals of the New York Academy of Sciences, 1316(1), 105-133.

Roy, D.S., Arons, A., Mitchell, T.I., Pignatelli, M., Ryan, T.J., \& Tonegawa, S. (2016). Memory retrieval by activating engram cells in mouse models of early Alzheimer's disease. Nature, 531(7595), 508-512. doi: 10.1038/nature 17172

Summers, W.K., Robins, E., \& Reich, T. (1979). The natural history of acute organic mental syndrome after bilateral electroconvulsive therapy. Biology Psychiatry, 14(6), 905-912.

Talmi, D., Grady, C.L., Goshen-Gottstein, Y., \& Moscovitch, M. (2005). Neuroimaging the serial position curve: A test of single-store versus dual-store models. Psychological Science, 16(9), 716723.

Tarnow, E. (2008). Response probability and response time: a straight line, the Tagging/Retagging interpretation of short term memory, an operational definition of meaningfulness and short term memory time decay and search time. Cognitive neurodynamics, 2(4), 347-353. doi: 10.1007/s11571008-9056-y.

Tarnow, E. (2009). Short term memory may be the depletion of the readily releasable pool of presynaptic neurotransmitter vesicles of a metastable long term memory trace pattern. Cognitive neurodynamics, 3(3), 263-269. doi: 10.1007/s11571-009-9085-1.

Tarnow, E. (2015) First direct evidence of two stages in free recall and three corresponding estimates of working memory capacity. RUDN Journal of Psychology and Pedagogics, (4), 15-26.

Tarnow, E. (2016a) Indirect Evidence: Mild Alzheimer's Disease \& Cannabis Affect the Second State of Free Recall Suggesting Localization in Hippocampal CA1. RUDN Journal of Psychology \& Pedagogics, (2), 36-44.

Tarnow, E. (2016b). Preliminary Evidence--Diagnosed Alzheimer's Disease But Not MCI Affects Working Memory Capacity-0.7 of 2.7 Memory Slots is Lost. arXiv preprint arXiv:1603.07759.

Teter, B., \& Ashford, J. W. (2002). Neuroplasticity in Alzheimer's disease. Journal of neuroscience research, 70(3), 402-437. doi: 10.1002/jnr.10441.

(C) Tarnow, E., 2017 
Article history:

Received 20 April2017

Revised 7 June 2017

Accepted 14 June 2017

For citation:

Tarnow, E. (2017) ECT Damage Indicates STM Divided into STM Control \& LTM Traces: Confusion Defined. RUDN Journal of Psychology and Pedagogics, 14 (3), 273-281. DOI 10.22363/2313-1683-2017-14-3-273-281

\title{
Bio Note:
}

Eugen Tarnow - Ph.D., Data Scientist, Director of Consulting Avalon Business Systems (New York, USA). E-mail: etarnow@avabiz.com

\section{ПОВРЕЖДЕНИЯ В РЕЗУЛЬТАТЕ ЭЛЕКТРОСУДОРОЖНОЙ ТЕРАПИИ КАК ПОКАЗАТЕЛЬ ДВУХ ЭТАПОВ ВОСПРОИЗВЕДЕНИЯ ИЗ КРАТКОВРЕМЕННОЙ ПАМЯТИ: НЕВРОЛОГИЧЕСКОЕ ОБЪЯСНЕНИЕ}

\author{
Юджин Тарноу \\ Авалон Бизнес Системс, Инк. \\ 18-11 Редбурн Роад, Фейр Лоун, Нью-Джерси 07410, США
}

В последнее время было показано, что свободное воспроизведение из кратковременной памяти (КП) состоит из двух этапов: первые несколько воспроизведений «опустошают» рабочую память, второй этап имеет характер реактивации [Tarnow, 2015; обзор теоретических предпосылок представлен Мердоком (1974)]. Бейли с соавт. (Bayley et al., 2000) исследовали свободное воспроизведение у людей, прошедших электросудорожную терапию (ЭСТ), и обнаружили, что эффекты и новизны, и первичности остались нормальными. В данной работе исследование было продолжено для проверки предположения о том, что воспроизведение из КП происходит под контролем КП и четко отделено от следов долговременной памяти, при этом ЕСТ не оказывает влияния на функции контроля КП.

Данные из исследования Бейли с соавт. (Bayley et al., 2000) были использованы для сравнения КП 11 пациентов, подвергавшихся ЭСТ, с контрольной группой (50 человек) и группой пациентов с болезнью Альцгеймера (50 человек).

Выявлены различия в вероятности свободного воспроизведения из КП и общей вероятности воспроизведения. Это подтверждает, что контроль КП (отвечающий за рабочую память и реактивацию) отделен от следов долговременной памяти (отвечает за общую вероятность воспроизведения информации).

Опираясь на обзор Эббота с соавт. (Abbott et al., 2014a), показывающий избыточную активность в височных долях мозга и отсутствие активности в лобных долях при ЭСТ, можно предположить, что контроль КП перегружен работой в процессе установки стабильных связей в долговременной памяти. Возможно, нарушения воспроизведения, возникающие в результате ЭСТ, связаны с ошибками в этом процессе, что указывает на неврологическую природу данных нарушений. 
Ключевые слова: электросудорожная терапия (ЭСТ), свободное воспроизведение, рабочая память, кратковременная память (КП), долговременная память, кривая воспроизведения, нейропластичность

\section{История статьи:}

(C) Тарноу Ю., 2017

Поступила в редакцию: 20 апреля 2017

Принята к печати: 14 июня 2017

\section{Для цитирования:}

Тарноу Ю. Повреждения в результате электросудорожной терапии как показатель двух этапов воспроизведения из кратковременной памяти: неврологические объяснение // Вестник Российского университета дружбы народов. Серия: Психология и педагогика. 2017. Т. 14. № 3. C. 273-281. DOI 10.22363/2313-1683-2017-14-3-273-281

\section{Сведения об авторе:}

Тарноу Юджин - Ph.D., независимый исследователь, директор, Авалон Бизнес Системс, Инк (Нью-Йорк, США). Е-mail: etarnow@avabiz.com 